\title{
Linguistic Rights and Education in the Republics of the Russian Federation: Towards Unity through Uniformity
}

\author{
Szymon Jankiewicz \\ Center for Education Law of the Institute of Education, \\ Higher School of Economics, Moscow, Russian Federation \\ syankevich@hse.ru \\ Nadezhda Knyaginina \\ Center for Education Law of the Institute of Education, \\ Higher School of Economics, Moscow, Russian Federation \\ nknyaginina@hse.ru
}

\section{Federica Prina}

School of Social and Political Sciences, University of Glasgow, Glasgow, United Kingdom federica.prina@glasgow.ac.uk

\begin{abstract}
This article traces the evolution of the debate on the balancing of federal and regional competences in regulating the use of minority languages in Russia's education system. Taking into account relevant law and judicial practice, as well as developments in center-periphery relations since 2017 , the article argues that the federal center has been increasingly depriving Russia's republics of the ability to self-regulate in the education sphere - particularly over the question as to whether they may require the compulsory study of republican languages (recognized as co-official with Russian) in schools located within their administrative borders. These processes can be located in the context of the centralization of the education system and a corresponding reduction of multilingualism in Russia's schools. This can, in turn, be seen as part of an underlying drive to promote national unity through uniformity, through the dilution of the country's linguistic and cultural diversity and a concurrent emphasis on the primacy of the Russian language. The article further argues that the Russian education system's centralization has been ongoing: while it has intensified since 2017, the


trajectory of the jurisprudence shows an earlier movement towards a concern for 'unity' that anticipated it.

\section{Keywords}

Russian Federation - education - minority languages - linguistic rights - Russian Constitutional Court - Russian Supreme Court

Linguistic policy in the Russian Federation's education system, particularly relating to the teaching of languages recognized as official at the level of its republics, has long been a subject of debate. The issue has sparked disagreements on the balancing between federal and regional competences in regulating the use of languages in education, as well as revealing a tension between Russia's linguistic diversity and the (de jure and de facto) dominance of Russian as the state language of the Federation. The latest manifestation of this debate has centered around renewed frictions on the question as to whether Russia's republics may impose an obligation to study languages recognized as co-official with Russian in schools located within their administrative borders. The ensuing disputes have become so severe as to lead to mass prosecutorial inspections of Russia's republics in 2017.

The inspections were triggered by a speech given by President Vladimir $\mathrm{Pu}-$ tin on 20 June 2017, at a meeting of the Council on Inter-ethnic Relations in Yoshkar-Ola (in Russia's Republic of Mari El). ${ }^{1}$ The speech was partially devoted to language rights: it was stated, inter alia, that in no case can the time allocated to the study of Russian be reduced in the republics' schools, and nobody should be forced to study a language that is not native to them. Prosecutorial inspections ${ }^{2}$ aimed at establishing whether or not the study of republican languages was voluntary; indeed, the position of the Prosecutor General's Office - which mirrors Putin's - has been that the compulsory study of these languages amounts to interference in (federal-level) processes of

1 "Vladimir Putin v Yoshkar-Ole provel zasedanie Soveta po mezhnatsional'nym otnosheniyam" [In Yoshkar-Ola Vladimir Putin held a meeting of the Council on Inter-ethnic Relations], Pervyi Kanal (20 July 2017), available at: https://www.1tv.ru/news/2017-07-20/329185 -vladimir_putin_v_yoshkar_ole_provel_zasedanie_soveta_po_mezhnatsionalnym_otnosheniyam.

2 'Putin poruchil Chaike proverit' dobrovol'nost' izuchenia natsional'nikh yazyov - srok do 30 noyabrya" [Putin instructed Chaika to verify whether the study of national languages is voluntary for the period until 20 November], BiznesOnline (31 August 2018), available at: https:// www.business-gazeta.ru/news/356052. 
devising education programs, as well as violating the right of individuals to choose their language of instruction. In reality, this position contradicts principles found in a series of judgments by the Russian higher courts, which have held the compulsory study of republican languages (in the republics themselves) compatible with federal legislation. ${ }^{3}$ The inspections triggered tensions between actors on both sides of the debate, with, on the one hand, demonstrations in the republics and public statements by the regional authorities protesting against these developments, and, on the other, support for the position of the Prosecutor General's Office. The debate was brought to a halt in mid2018, as the Russian State Duma adopted amendments to the Federal Law on Education. The amendments effectively blocked the option for the republics to require the compulsory study of regional languages, while also strengthening the role of the Russian language.

In this article we trace the evolution of the debate on the study of regional languages in Russia's ethnic republics. The article is divided into two main sections. In the first part, following a brief introduction of Russia's history of multilingualism and diversity management, we outline federal legislation on regional-language education, as well as recent developments linked to the language dispute sparked by Putin's speech in Yoshkar-Ola. Second, we consider cases from the Russian courts on the compulsory study of regional languages, highlighting principles that can be drawn from the jurisprudence. We argue that the federal center has been increasingly depriving the republics of the ability to self-regulate in the use of minority languages in the education system. These dynamics can be located in the context of the centralization of the education system and a corresponding reduction of multilingualism in Russia's schools. This can, in turn, be seen as part of an underlying drive to promote national unity through uniformity, in the sense of dilution of the country's linguistic and cultural diversity and concurrent emphasis on the primacy of the Russian language as a "unifying factor" 4 for the citizenry as a whole. We further

3 These judgments are described in the second half of this article.

4 E.g., in his 2017 Yoshkar-Ole speech, Putin recalled that Russian was not only the country's "language of inter-ethnic communication", but also "the natural spiritual framework of our entire multinational country”. Perryi Kanal, op.cit. note 1. See also, inter alia, Putin's 2012 state of the nation address:

For centuries, Russia developed as a multi-ethnic nation ... a civilization-state bonded by the Russian people [russkii narod], Russian language and Russian [russkii] culture native for all of us, uniting us and preventing us from dissolving in this diverse world.

President of Russia, Address to the National Assembly of the Russian Federation (12 December 2012), http://eng.kremlin.ru/transcripts/4739. Similar wording can be found in the 2012 
argue that the education system's centralization has been ongoing: while its clearest manifestation thus far has been the events since 2017, the trajectory of jurisprudence has also reflected a trend towards unity and uniformity, in disregard of earlier judicial practice.

\section{Languages in the Education System: Law and Practice}

According to data from the 2010 All-Russian Population Census, individuals belonging to more than 160 ethnic groups live in Russia, while their languages belong to 14 language families. ${ }^{5}$ In total approximately 180 languages and dialects are spoken in the country. Not all these languages are employed in official channels: some of them are, rather, endangered languages, whose use is confined to small villages, and which only count a few dozen speakers. There are grounds to believe that in the near future these languages will disappear. ${ }^{6}$

A useful indicator in assessing the number of languages actively employed in Russia is the use of languages on the Internet. In the study "Languages on the Internet", conducted by Moscow's Higher School of Economics, researchers analyzed what languages are employed in the Russian segment of the Internet to publish articles and to post information. The study revealed that 96 languages are used, ${ }^{7}$ demonstrating that the country's linguistic diversity is considerable. $^{8}$

Presidential Decree "On the Strategy of State Nationality Policy of the Russian Federation until 2025", No 1666, 19 December 2012.

5 All-Russia Population Census 2010, available at: http://www.gks.ru/free_doc/new_site/pere pis2010/croc/perepis_itogi1612.html.

6 In fact, according to the Unesco Atlas of the World's Languages in Danger, even the more widely spoken languages are endangered, with 131 languages of the Russian Federation under threat in 2010. This included most of the languages recognized as co-official in the republics (alongside Russian), ranging from "vulnerable", to "definitely endangered", to "severely endangered”. Christopher Moseley (ed.), Atlas of the World's Languages in Danger (unesco Publishing, Paris, 2010, $3^{\text {rd }}$ ed.).

7 Boris Orekhov, Irina Krylova, Ivan Popov, Ekaterina Stepanova, Ludmila Zaydelman "Russian Minority Languages on the Web: Descriptive Statistics // Computational Linguistics and Intellectual Technologies", in Proceedings of the Annual International Conference «Dialogue» (Russian State University for the Humanities, Moscow, 2016), 498-508.

8 The study was based on data collected in 2014 and 2015 through an automatic "seed words" method in the Russian segment of the Internet, especially in articles in Wikipedia on the languages spoken in Russia, and texts from Vkontakte (a popular Russian social network). 


\subsection{Russia's Multilingualism}

Multilingualism has been a constant feature of Russian history. As the Russian empire annexed new territories, it also incorporated a multi-ethnic, multiconfessional population, speaking a myriad of languages. While waves of Russification took place, these policies were selectively applied, with some ethnic groups retaining a degree of local or regional autonomy, including in cultural and linguistic matters. ${ }^{9}$ Faced with the same ethnic, cultural and linguistic diversity, the Bolsheviks sought to devise policies that would manage it, so as to contain nationalist impulses while incorporating highly diverse communities into the Communist project. Among the main features of Soviet nationalities policy was ethno-territorial federalism - by which territories were nominally assigned to the main ethnic groups. ${ }^{10}$ These territorial arrangements ${ }^{11}$ have been preserved to this day: currently the Russian Federation comprises 83 'subjects' (federal constituent units) (85 with the annexation of Crimea and Sevastopol). The subjects include 21 republics, ${ }^{12}$ which are generally referred to as 'ethnic republics'13 in light of the (one or more) titular nationalities after which they are named.

Alongside ethnic federalism, Soviet nationalities policy introduced programs promoting linguistic and cultural diversity, including through language policies and education in multiple languages. ${ }^{14}$ Meanwhile, the regions were administered through local elites (recruited into the Communist Party) via the

Bill Bowring, Law, Rights and Ideology in Russia: Landmarks in the Destiny of a Great Power (Routledge, London, 2013), 120-38. E.g., from the $16^{\text {th }}$ century, an agreement between Moscow and the Kazan and Astrakhan khanates enabled Tatars to retain their language and religion, as well as their lands, in exchange for loyalty to the tsar. Oleg E. Kutafin, Rossiiskaya Avtonomiya [Russian Autonomy] (Prospekt, Moscow, 2006).

10 E.g., the Tatar Autonomous Soviet Socialist Republic, today the Republic of Tatarstan within the Russian Federation.

11 In what was once the Russian Soviet Federative Socialist Republic.

1222 if counting Crimea.

13 Even though the Russian Constitution does not employ this particular expression.

14 According to Anderson and Silver, the Soviet Union had a "longer and more extensive experience with bi-lingual education than any other country in the world". Barbara A. Anderson and Brian D. Silver, "Equality, Efficiency, and Politics in Soviet Bilingual Education Policy, 1934-1980", 78(4) The American Political Science Review (1984), at 1019. See also: Michael Kirkwood (ed.), Language Planning in the Soviet Union (Macmillan, London, 1989); E Glyn Lewis, Multilingualism in the Soviet Union: Aspects of Language Policy and its Implementation (Mouton, The Hague, 1972); Terry Martin, The Affirmative Action Empire (Cornell University Press, Ithaca, NY, 2001); Yuri Slezkine, "The UssR as a Communal Apartment, or How a Socialist State Promoted Ethnic Particularism", 53(2) Slavic Review (1994), 413-452. 
process of korenizatsiya (indigenization). What the Soviet Union created has been described as "the most ambitious affirmative action programme in history"; 15 however, the use of minority languages (and minority-language education) was reduced from the 1930s onwards, while the use of Russian as the language of inter-ethnic communication increased. New policies emphasized the importance of Russian in the unification of the Soviet people and the country's modernization - as well as becoming a prerequisite for social mobility. ${ }^{16}$ These policies resulted in a decline of national schools, and a tendency to confine the use of minority languages to non-urban areas. ${ }^{17}$

Ethnic federalism, korenizatsiya and ethnic institutions effectively created the conditions for ethnic mobilization during perestroika and the 199os. ${ }^{18}$ This period saw the revival of minority (particularly titular) languages, as a fundamental aspect of non-Russian groups' nationalist projects. Access to titular-language education was greatly enhanced in some republics, particularly Tatarstan. ${ }^{19}$ Ethnic revival was accompanied by decentralization under Yeltsin - processes for the most part reversed since the 200os, through Putin's emphasis on political centralization and state consolidation. ${ }^{20}$ Among the consequences of Putin's policies has been a form of cultural homogenization (the tendency towards 'uniformity' referred to in this article), through the primacy of the Russian language, culture and symbols. ${ }^{21}$

15 Martin (op.cit. note 14), 2.

16 See also Aneta Pavlenko, "Multilingualism in Post-Soviet Countries: Language Revival, Language Removal, and Sociolinguistic Theory”, in Aneta Pavlenko (ed.), Multilingualism in Post-Soviet Countries (Multilingual Matters, Bristol, 2008).

17 Dmitry P. Gorenburg, "Tatar Language Policies in Comparative Perspective: Why Some Revivals Fail and Some Succeed", 1 Ab Imperio (2005), 1-28, at 3-6.

18 Dmitry P. Gorenburg, Minority Ethnic Mobilization in the Russian Federation (cup, Cambridge, 2003); Ronald Grigor Suny, The Revenge of the Past: Nationalism, Revolution, and the Collapse of the Soviet Union (Stanford University Press, Stanford, CA, 1993).

19 Gorenburg, op.cit. note 18; Yagfar G. Garipov and Helen M. Faller, "The Politics of Language Reform and Bilingualism in Tatarstan", in Farimah Daftary and François Grin (eds.), Nation-Building, Ethnicity and Language Politics in Transition Countries (Open Society Institute, Budapest 2003); Katherine E. Graney, "Education Reform in Tatarstan and Bashkortostan: Sovereignty Projects in Post-Soviet Russia" 51(4) Europe-Asia Studies (1999), 611-632; Konstantin Zamyatin, "From Language Revival to Language Removal? The Teaching of Titular Languages in the National Republics of Post-Soviet Russia", 11(2) Journal on Ethnopolitics and Minority Issues in Europe (2012), 75-102.

20 Recently, there has been an emphasis on security in the sphere of inter-ethnic relations. Bill Bowring, "National Developments-Russia Emphasis on Crimea, Russian Language, and National Security", 14(1) European Yearbook of Minority Issues (2017), 186-198.

21 Federica Prina, National Minorities in Putin's Russia: Diversity and Assimilation (Routledge, London, 2016), Ch 5 . 
Against this backdrop - and despite Russia's multilingualism and tradition of minority-language education - the past few years have seen the emergence of new challenges to the use of languages other than Russian in the education system. The reduction of Russia's linguistic diversity has been disputed by the Russian government, for example in its latest (2016) report to the Council of Europe's Advisory Committee on the Framework Convention for the Protection of National Minorities (ACFC), which refers to the high number of languages employed in the Russian education system. ${ }^{22}$ The ACFC, in its own monitoring, has pointed to the fact that:

[T] he teaching and learning in and of minority languages is on the whole diminishing. [...] [I]n general teaching in the minority language was scarce after primary school. Moreover, information [...] indicates a decrease in the number of schools where minority languages are taught or used a medium of instruction, of the hours dedicated to teaching minority languages, and changes in their status from compulsory to optional or extra-curricular. ${ }^{23}$

A range of studies have similarly supplied evidence on the generalized decrease in minority-language education. ${ }^{24}$ Overall, the presence of regional languages

The Russian government report states that:

Currently 34 languages of [the] peoples of Russia are the state languages of the republics in the Russian Federation and can be used in these constituent entities on a par with the Russian language. According to the statistical surveillance in the 2014/2015 academic year, in addition to the Russian language as the state language of the Russian Federation, the training was conducted in the 24 official languages of the republics belonging to the Russian Federation, and 73 languages of the peoples of Russia are studied as a subject. [...].

Fourth Report submitted by the Russian Federation pursuant to Article 25, paragraph 2 of the Framework Convention for the Protection of National Minorities, received on 20 December 2016, ACFC/SR/IV(2016)oo6, p. 65, https://rm.coe.int/168o6fd935.

23 Advisory Committee on the Framework Convention for the Protection of National Minorities (ACFC), Fourth Opinion on the Russian Federation, adopted on 20 February 2018, ACFC/OP/IV(2018)oo1, https://rm.coe.int/4th-advisory-committee-opinion-on-therussian-federation-english-langu/1680908982, para. 128. The ACFC further referred to the centralization of the education system (and the reduced autonomy of the regions) through legislation in 2007; the fact that the "unified state examination" may only be taken in Russian, irrespective of the language of instruction; and the closure of (mostly village) schools with teaching in and of minority languages. ACFC, paras. 129-131.

24 For details, see: Zamyatin, op.cit. note 19; Konstantin Zamyatin, An Official Status for Minority Languages? A Study of State Languages in Russia's Finno-Ugric Republics (Uralica Helsingiensia, Helsinki, 2014); Konstantin Zamyatin, "The Education Reform in Russia 
in Russia's education system has been found to be insufficient to assure intergenerational transmission. ${ }^{25}$ In particular, the fact that teaching in minority languages is scarce after primary school is problematic: as the ACFC has stressed, in order to develop minority-language skills "there must be continuity in access to teaching and learning of and in minority languages at all levels of the education system, from pre-school to higher education." ${ }^{26}$ [italics added].

Not only have these developments created a weak system of minoritylanguage education but they have also resulted in an ongoing (and intensifying) tension between knowledge of Russian as the state language for the whole country (as a "unifying factor" for its population), and Russia's multilingual environment. Centralization - particularly recent developments described in this article - has ultimately tipped the balance towards increased uniformity.

\subsection{Legal Provisions}

The principal legal provisions relating to language rights in the education sphere are included in federal legislation. In particular, Article 68(1) of the 1993 Constitution of the Russian Federation (hereinafter 'the Constitution') stipulates that Russian is the state language for the entire country. The state language is employed in the administration, the judiciary, the media and in various other spheres. ${ }^{27}$ In education the status of the state language is reaffirmed

and Its Impact on Teaching of the Minority Languages: An Effect of Nation-Building?" 11(1) Journal on Ethnopolitics and Minority Issues in Europe (2012), 17-47; Konstantin Zamyatin, "Finno-Ugric Languages in Russian Education: The Changing Legal-Institutional Framework and Falling Access to Native Language Learning", 44 Études Finno-Ougriennes (2012), 2-44; Hèctor Alòs i Font, "Chuvash Language in Chuvashia's Instruction System: An Example of Educational Language Policies in Post-Soviet Russia", 13(4) Journal of Ethnopolitics and Minority Issues in Europe (2014), 52-84; Federica Prina, "Localism or Centralism? Education Reform in Russia and Its Impact on the Rights of National Minorities", 42 Cambrian Law Review (2011), 113-130; Prina op.cit. note 21.

25 Zamyatin, op.cit. note 19.

26 Para. 127. See also ACFC Thematic Commentary No 3 "The Language Rights of Persons belonging to National Minorities under the Framework Convention", May 2012, para. 75 . The ACFC added that:

Pre-school is, together with secondary education, the level where particular weaknesses in the offer of minority language education are often observed. The Advisory Committee underlines that the lack of incentives or insufficient possibilities at preschool, secondary or higher level can seriously reduce the attractiveness of minority language learning at primary level. (para 127)

27 Art. 3, Federal Law "On the State Language of the Russian Federation", 1 June 2005, No 53 -FZ.

28 Law "On the State Language", Ibid. 
by the right to receive an education in Russian in public schools, which is held by every resident in the country as laid down in the 2005 Federal Law "On the State Language of the Russian Federation", ${ }^{28}$ and the 2012 Federal Law "On Education in the Russian Federation"29 (hereinafter 'Law on Education'30). At the same time, education may also take place in other languages - an option enabled by several factors. First, the Constitution foresees the right to choose the language of instruction and the right to use one's native language (Article $26(2)) .{ }^{31}$ Second, education- and language-related legislation does not specify that schools should employ exclusively Russian. Third, the Constitution enshrines a prohibition of discrimination, including on linguistic grounds (Article $19(2)),{ }^{32}$ while also guaranteeing the preservation of the languages spoken in Russia (Article 68(3)). ${ }^{33}$

Besides "state language", Russian legislation contains the expression "native language". However, in the regulation of linguistic rights, a more common expression is "languages of the peoples [narody] of the Russian Federation", in accordance with the lex specialis regulating language matters, namely the Federal Law "On the Languages of the Peoples of the Russian Federation". ${ }^{34}$ This law stipulates the equality of languages (Article 2(1)), along with the option to use languages other than Russian in the administration of designated regions, where their speakers reside compactly (Article 3(4)).

Clearly not in all cases can linguistic diversity be supported through the education system, given its finite resources. Consequently, the legislation

29 Federal Law “On Education in the Russian Federation", 29 December 2012, No 273-FZ.

30 It replaced the Law "On Education" of 10 July 1992, No 3266-1.

31 Art. 26(2) states:

Everyone shall have the right to use his or her native language, to a free choice of the language of communication, upbringing, education and creative work.

32 Art. 19(2) stipulates:

The State shall guarantee the equality of rights and freedoms of man and citizen, regardless of sex, race, nationality, language, origin, property and official status, place of residence, religion, convictions, membership of public associations, and also of other circumstances. All forms of limitations of human rights on social, racial, national, linguistic or religious grounds shall be banned.

The Russian Federation shall guarantee to all of its peoples the right to preserve their native language and to create conditions for its study and development.

34 Federal Law "On the Languages of the Peoples of the Russian Federation", 25 October 1991, No 1807-1. 
states that the right to choose the language of education is to be realized "within the limits of the opportunities provided by the education system". ${ }^{35}$ Thus, in practice, despite the legal right to choose the language of instruction, the state does not guarantee the right for every student to attend a school where instruction is provided in their native language, or where such a language is taught. If a region is equipped with the means and personnel to realize a policy of linguistic diversity in line with local demand, its schools will use as the language of instruction - or teach - one of the languages of the peoples of Russia (alongside Russian); yet, if resources are unavailable, instruction can only take place in Russian.

Federal legislation also regulates the "state languages of the republics": 36 these may be declared official by the republican organs pursuant to Article 68(2) of the Constitution. They are recognized as state languages of the republics as opposed to Russian as the state language (for the country in its entirety); they are also referred to interchangeably in this article as 'a republic's official languages', 'republican languages' or 'regional languages'. Nearly all of Russia's ethnic republics - the Republic of Karelia being the exception - have established their own official languages. The state language of a republic constitutes an aspect of the republic's public policy, and a manifestation of its sovereignty. The languages in question are afforded special status in republican legislation and they may be employed alongside Russian within the republics, in spheres such as communication with administrative authorities, publication of official documents, provision of services by state institutions, media activity, and websites of state organs. One should note that the republican languages are more numerous than the republics themselves, given that some republics have assigned a special status to more than one language. The cases in question are: Karachay-Cherkessia (5 languages), Kabardino-Balkaria (2), Mordovia (2), and Dagestan, where the exact number of state languages remains undefined. ${ }^{37}$

35 Art. 14(1), Law on Education op.cit. note 29.

36 Art. 68(2), Russian Constitution:

The Republics shall have the right to establish their own state languages. In the bodies of state authority and local self-government, state institutions of the Republics they shall be used together with the state language of the Russian Federation.

37 In the case of Dagestan, the expression "languages of the peoples of Dagestan" is used, with scholars estimating that there are 13 languages among those that have a written form (and that should therefore be considered as "state languages of the republic"). 
Article 14(3) of the Law on Education states that, within a republic, the study of its official language(s) may be introduced. The Law on Education does not clarify whether this may be compulsory; rather, it includes a set of restrictions, such as that the study of a republican language should not occur to the detriment of the study of Russian (Article 14(3)). In most cases, the republics reproduce the same legal principles in their own regional legislation; thus, republican laws, for the most part, do not include the right (or the obligation) to learn the language(s) of the republic - as 'native language(s)' of its residents or as 'state language(s) of the republic's8 - and nor do they prohibit introduction of these languages as compulsory subjects.

In order for a language to be studied in a particular school, it has to be added as a subject in its educational program (the school curriculum). The program is developed autonomously by the school, although it has to comply with Federal State Educational Standards (FSES). ${ }^{39}$ The existence of these standards is provided for in the Constitution (Article 43(5)) and their content by the Law on Education: according to Article 11 of the latter, the FSES define the criteria for formulation of the program of education, the conditions for its realization, and the expected results. The FSES are detailed in decrees of Russia's Ministry of Education and Science (hereinafter the 'Ministry of Education'), ${ }^{40}$ themselves approved by the Russian government.

Until 2007, the FSES had three components: the federal level, the regional level and the individual school, each contributing to the curriculum. The regional component (known as the "national-regional component") concerned school subjects specifically relating to the regions, such as their history and literature, and amounted to $15 \%$ of total teaching time. The other two components were devised at the federal and local level. After 2007 the concept of

38 The Constitution foresees the right to choose the language of instruction and the right to use one's native language (Article 26(2)).

39 Standards exist for every level of education. The relevant provisions are Decrees of the Ministry of Education and Science of the Russian Federation: Decree "On the Approval and Implementation of Federal State Educational Standards of Primary General Education", 6 October 2009, No 373; Decree "On Approval of the Federal State Educational Standards of Basic General Education”, 17 December 2010, No 1897; Decree "On Approval of Federal State Educational Standards of Secondary General Education”, 17 May 2012, No 413 .

40 In 2018 the Ministry of Education and Science of Russian Federation was split into the Ministry of Education of the Russian Federation (concerned with pre-school and school education) and the Ministry of Science and Higher Education of the Russian Federation. 
FSES changed radically as the regional component was removed, ${ }^{41}$ with the curriculum being divided between the "obligatory" $(70 \%$, devised at the federal level) and "variable" parts (30\%, established by "participants in the education process" - or students, their parents and school officials in individual schools).$^{42}$ The fact that decision-making on the "variable part" of the curriculum may only be at the local level - without direct regulation by the republican authorities - means that FSES regulations have effectively blocked the republics' ability to establish the compulsory study of their languages. Representatives of Russia's subjects may be invited by the Ministry of Education to participate in the process of formulating the FSES, yet there is no obligation on the part of the Ministry to do so. 43

The FSES do not contain the expression "state language of republics" as a compulsory subject, but only "state language" (Russian) and "native language". In practice republican languages may be included only in the "variable" part of the education program (not affecting compulsory subjects established at the federal level). If Russia's Ministry of Education introduced the "state languages of the republics" as an obligatory subject in the FSES, each republic's language(s) would have to be taught in all schools within its territory. The Ministry of Education could also introduce a regulation that the study of these languages be mandatory only when specifically declared in republican legislation. ${ }^{44}$ This would, among other things, increase the financial viability of the study of languages other than Russian, since each republic - like other subjects of the Federation - is financially responsible for public education within its territory. Republics would then be in a position to directly assess the financial feasibility (and desirability) of supplementary school subjects in their programs, while also giving them the authority to ultimately decide on these matters. Russia's Ministry of Education had not initiated these changes at the time of writing.

41 Law "On the Amendment of Legal Acts of the Russian Federation Modifying the Concept and Structure of State Education Standards", 1 December 2007, No 309-FZ. See also Prina, op.cit. note 24 ("Localism or Centralism?...", 2011).

42 Resolution of the Government of the Russian Federation "On Approval of Model Provisions for Institutions of General Education", 18 March 2001, No 196, para 44. The document states that "participants in the education process" are "students, the teaching staff, and the students' parents".

43 See also the judgment reported below, on Sakha.

44 However, it is not clear how the compulsory status of the "state language of republics" would be combined with legal provisions introduced in August 2018 (see below, nn 6970), on the "free choice of the language of instruction" (Art. 14(6), Law on Education). In order for the republican languages to become compulsory subjects, it would be necessary to amend Article 14(6). 
Eight republics introduced legal provisions prescribing the compulsory study of republican languages. In Tatarstan and Chechnya, regional legislation stipulates that republican languages (Tatar and Chechen) are to be studied "in equal measure" with Russian. In North Ossetia the study of Ossetian is compulsory for all students enrolled in public schools, along with study of the history, literature and culture of Ossetians. Dagestan's public schools require the study of one or more republican languages. In the Republic of Komi the study of the titular language is similarly compulsory in all schools, while in Adygea the mandatory study of Adyge is limited to speakers of the language. In two cases the Republics of Kalmykia and Karachay Cherkessia - legislation was amended following the 2017 prosecutorial inspections, to remove the legal requirement of compulsory study of the titular language. ${ }^{45}$ In other republics - Bashkortostan and Ingushetia - there is no legal clarity as to whether the study of the relevant languages is compulsory. ${ }^{46}$ Thus, legal provisions vary among regions, from the obligation for all students to study official languages - including intensively ("in equal measure" with Russian) - to the obligation being confined to a section of the student population. Some provisions regulating compulsory study of republican languages have been challenged through the courts, ${ }^{47}$ as well as by prosecutorial inspections.

Even when regional legislation envisages the study of the republics' state languages for all students - and continues to be applied despite prosecutorial inspections - the general trend has been, as noted, a reduction in the time devoted to study of (or in) regional languages.

\subsection{The Language Dispute and its Outcome}

As mentioned above, the language dispute was triggered by the July 2017 speech in Yoshkar-Ola. The main item on the event's agenda was the implementation of linguistic rights as part of Russian policies on nationalities and inter-ethnic relations. The points made by President Putin in his speech which are relevant to this article are: the Russian language is "the natural spiritual

\footnotetext{
45 See the next section.

46 Protests that took place in 2017 in Bashkortostan, linked to the prosecutorial inspections, show that, before the inspections, in practice the study of the republic's titular language took place in all its public schools. This was stated by the protesters, members of the Committee for the Protection of Rights of Russian-Speaking Bashkir Students, with reference to their own school audits. See "Bashkiriya — yazykovoj front: nesanktsionirovannyj miting, petitsii, ukazy” [Bashkiria - language front: unauthorized rally, petitions, decrees], Regnum (15 September 2017), available at: https://regnum.ru/news/2322673.html.

See below (“2. Jurisprudence”).
} 
framework of our multinational country"; every Russian citizen should speak the state language; nobody can be forced to learn a language that is not native to them; the time for the study of Russian in public schools, as allocated by FSES, may not be reduced.

The language conflict that followed the Yoshkar-Ola speech had a legal basis. On the one hand, linguistic rights in Russian legislation hinge both on Russian as the state language and the language of the peoples of Russia; on the other, the republics have the right to establish their own state languages - a right which the republics have used. Moreover, that right is linked to the national-territorial (ethnic-territorial) principle which historically has been at the basis of the existence of the republics. ${ }^{48}$ That the republics may establish their own state languages is one of few entitlements reserved to them, which allows us to refer to Russia as an asymmetric federation. ${ }^{49}$ At the same time, it has already been noted that the education sphere, which is at the heart of the conflict, is regulated - in many respects - at the federal level. The language conflict has rekindled tensions that also emerged from Russian jurisprudence since 2001, as will be seen in the next section.

The position of the Prosecutor General's Office has been that the state language of a republic may be used alongside Russian in the administration, but its study may not be obligatory in schools. The Prosecutor General's Office insisted that compulsory study of the republican languages by all pupils entails a double problem: violation of students' right to choose their language of education, ${ }^{50}$ and a breach, on the part of the republics, of federal requirements (in particular, the FSES, which do not envisage the compulsory study of republican languages). ${ }^{51}$ However, given the approach of the Prosecutor General's Office, republican languages - which are to be employed in the republics' administration - are not supported throughout the education system.

48 See above ("1.1 Russia's Multilingualism").

49 Only republics, and no other subjects, may do so.

5o Doklad prokurora Respubliki Tatarstan Ildusa Nafikova na tridcat' tret'em zasedanii Gosudarstvennogo Soveta Respubliki Tatarstan [Report of the Prosecutor of the Republic of Tatarstan Ildus Nafikov at the thirty-third meeting of the State Council of the Republic of Tatarstan], available at the official website of the Prosecutor's Office of the Republic of Tatarstan, https://www.prokrt.ru/prokuror/vystupleniya/3183/?sphrase_id=4691.

51 Federalizm ostalsya tol'ko na bumage [Federalism remained only on paper], Radio Svoboda (25 December 2017), available at https://www.svoboda.org/a/28933083.html. 
Protests took place in several regions ${ }^{52}$ among those which had required the compulsory study of republican languages. By contrast, two republics Kalmykia ${ }^{53}$ and Karachay-Cherkessiya ${ }^{54}$ - amended their legislation following the prosecuratorial inspections, excluding from their legislation the obligation to study titular languages. The remaining six republics which had included the mandatory study of republican languages in their legislation - Tatarstan, North Ossetia, Dagestan, Komi, Adygea, Chechnya - had not modified their laws at the time of writing. ${ }^{55}$

The situation changed in April 2018, when the country's legislative organ, the State Duma of the Russian Federation, intervened in the language conflict. A group of deputies initiated a draft law amending the provisions on use of languages in the education system contained in the Law on Education. ${ }^{56}$ The

52 For details, see Szymon Jankiewicz and Nadezhda Knyaginina, "Language Conflicts in Russia's Education System”, 16(1) European Yearbook of Minority Issues (2019), 188-210.

53 The old version of Art. 3(2) of the Law "On Education in the Republic of Kalmykia" stipulated that the Kalmyk language is a compulsory subject for all students in schools where instruction is in Russian. The new version establishes only that the teaching and learning of the Kalmyk language in public schools must correspond to the FSES. And, as noted, the FSES do not include such a subject in the mandatory part of the program, so compulsory language learning in the republic is no longer possible. See Law of the Republic of Kalmykia "On Amending Article 3 of the Law of the Republic of Kalmykia 'On Education in the Republic of Kalmykia", 21 November 2017, No 266-V-Z.

54 The Republic of Karachay Cherkessia amended Art. 5 of the Law "On Certain Issues in the Sphere of Education in the territory of the Karachay-Cherkess Republic". The old version established that, for native speakers of the one of the republic's languages, the study of the relevant language was mandatory if Russian was the language of instruction in their schools. The new version of the law excludes provisions about native speakers, and it states that that the study of the republican languages is to be in compliance with FSEs, and voluntary in the $10^{\text {th }}$ and 11 th grades. See Law of the Karachay-Cherkess Republic "On Amending Article 5 of the Law of the Karachay-Cherkess Republic 'On Certain Issues in the Sphere of Education in the territory of the Karachay-Cherkess Republic"', 29 December 2017, No 94-RZ.

55 On this issue, the ACFC regretted the fact that the language dispute has resulted in lowering of the status of minority languages (ACFC, op.cit. note 26 , paras 134-5). It noted that: "In the Advisory Committee's view, more time should be taken to reflect upon a solution that would accommodate both the need for sufficient hours of Russian language and the wish of the authorities in republics to develop a certain level of bilingualism of the population." (Ibid, para 135).

56 Draft Federal Law No, 438863-7 "On Amending the Federal Law 'On Education in the Russian Federation'" (concerning the teaching of native languages from the languages of peoples of the Russian Federation and state languages of the republics of the Russian Federation), available at: http://sozd.parliament.gov.ru/bill/438863-7. 
initial version of the draft law directly stipulated that "the teaching and study of the state languages of the republics of the Russian Federation is carried out on a voluntary basis". Another option discussed was to include in the draft law the right of parents to choose the language their children should study as their "native language" from the languages of peoples of the Russian Federation (which would also include republican languages), yet still as elective subjects. ${ }^{57}$ This led to a wave of criticism, especially in Tatarstan. ${ }^{58}$ A group of deputies from Tatarstan's regional parliament objected that republican languages should not be equated with "native languages", 59 as the former hold a special status which should be reflected in their role in the education system. The petition against the draft law reached over 40,000 signatures. ${ }^{60}$

During the debates on the first reading, it was clarified that the study of the subject "native language" would be compulsory, and that "native language" may coincide with the republican language. ${ }^{61}$ Although a number of deputies were against certain aspects of the draft law, it was adopted at the first reading, with 377 in favor, three abstentions and one against. Following the first reading, and in line with existing procedures, the relevant committees of the State Duma compiled written opinions. The Committee on Education and Science supported the draft law in principle, but stated that its text should be substantially modified; it proposed developing a Concept on the Teaching of Native Languages, to devise alterations to the FSES and assign appropriate funds for textbooks. The State Duma Committee on Nationalities argued that the voluntary nature of the study of republican languages which the draft law envisaged might lead to a decline in their quality of instruction. This was itself linked to having included languages in the "variable" (rather than the "obligatory") part of the education program, combined with a shortage of funds. According to the Committee on Education and Science, recommendations on the draft law were received by the parliaments of 69 subjects and 73 heads of subjects of the

57 These amendments would have required exclusion of the subject "native language" from the obligatory part of FSEs. Later the idea was abandoned.

$5^{8}$ "Pochemu nas khotyat lishit' rodnogo yazyka?: v Tatarii protiv popravok v FZ" [Why they want to deprive us of our native language?: Tataria against the amendments to the Federal Law], IA Regnum (25 April 2018), available at: https://regnum.ru/news/2408540.html. Ibid.

6o The petition is available at: https://www.change.org/p/президент-российской-феде рации-владимир-владимирович-путин-нет-закону-против-родных-языков.

61 IA Regnum, op. cit., note 58. 
Federation. The only negative opinion was submitted by the Tatarstani parliament. ${ }^{62}$

By the second reading, the draft law was markedly rewritten, and the new edition was supported by a majority of deputies. In a speech during the second reading, the Chairman of the State Duma Committee on Education and Science, Vyacheslav Nikonov, clarified that: a) amendments allow choice of Russian as the language studied as the subject "native language"; b) a special fund would be created to support the study of native languages; this would cover compiling and publishing textbooks in these languages, education programs, training of specialists and relevant research; ${ }^{63}$ and c) a working group would be created on development of the Concept on the Teaching of Native Languages, and measures introduced towards implementing the government's action plan. ${ }^{64}$

Following a range of discussions, the law was passed at the third reading (with 388 votes 'for' and 2 'against'). ${ }^{65}$ In the process of adoption of the law, two facts are noteworthy. First, deputies tried to resolve the tensions concerning the study of republican languages by calling on the Ministry of Education to alter the FSES. The amendments' final version stipulates that the FSES are to provide the opportunity to study the state languages of the republics as well as native languages selected from among the languages of the peoples of the Russian Federation (including Russian as a native language). However, in the months since the entry into force of the law, no information had transpired about new developments in this direction. Nevertheless, this step can be regarded as supporting the right of the republics to regulate the study of the relevant languages.

62 Opinion of the State Duma Committee on Education and Science on the Draft Federal Law "On Amending the Federal Law 'On Education in the Russian Federation", No 438863-7. The draft law concerned teaching native languages from the languages of peoples of the Russian Federation and state languages of the republics). Available at: http:// sozd.parliament.gov.ru/bill/438863-7. The opinions of the constituent entities' parliaments and heads are available at: http://sozd.parliament.gov.ru/bill/438863-7\#bh_comments .

63 The President of Russia signed a Decree about creation of this fund within three months (Decree of the President of the Russian Federation "On Creation of Fund of Preserving and Researching of the Languages of Peoples of the Russian Federation", 26 October 2018, No 688).

64 Information on activities in the field is not available in the public domain.

65 Federal Law "On the Amendments to Articles 11 and 14 of the Federal Law 'On Education in the Russian Federation"', No 317-FZ, 3 August 2018, available (in Russian) at https:// rg.ru/2018/08/07/317-fz-dok.html. 
The second development effectively precludes the study of such languages to be made mandatory. Amendments to the Law on Education refer to the free choice to study, as a part of the curriculum, students' native languages that correspond to the languages of the peoples of the Russian Federation, including Russian itself and the republican languages. ${ }^{66}$ The choice of language to be studied is made in line with a declaration by students' parents or legal guardians. ${ }^{67}$ Similar provisions have been replicated in regional legislation, such as in the Republic of Karachay-Cherkessia: under 2018 amendments, the right to study or receive an education in one's native language "includes Russian as native language". 68

The implications of applying the new legal provisions in relation to Russia's linguistic environment remain unclear. Overall, we may say that the conflict stemming from a lack of FSES provisions on the teaching of the republican languages ended with suppression of the republics' rights. Even if the republican languages were included in the FSES as a compulsory subject (as Russian and "native language"), in practice republican languages could only be taught on a voluntary basis, as these are equated to any other language native to the student (most students in Russia could be considered to have Russian language as native). In turn, the right to learn the native language is legally confined to "the limits of opportunities provided by the education system". 69 As a result, if in the past republican languages could be made obligatory by regional legislation through the national-regional component (thereby guaranteeing the possibility to study them), existing procedures imply that if no teachers or textbooks are available in a school for a particular language, one can refer to the fact that the "limits" have been reached, and that Russian can be treated as native language.

66 The amendments added a provision (para 5(1)) to Art. 11 of the Law, stating that the FSES at all levels of instructions "guarantee the opportunity" to a) "receive instruction in the native languages from the languages of the peoples of the Russian Federation"; and b) "study of the state languages of the republics of the Russian Federation, native languages from the languages of the peoples of the Russian Federation, including the Russian language as native language" [italics added].

67 Until students are no longer minors or until completion of basic general education. The new version of Art. 14(6) states that "free choice of the language of instruction" (which includes Russian as native language) is realized through a declaration by the parents (or legal guardians).

68 Law of the Karachay-Cherkess Republic "On Amending Article 5 of the Law of the Karachay-Cherkess Republic 'On Certain Issues in the Sphere of Education in the territory of the Karachay-Cherkess Republic"', 29 December 2018, No 96-RZ.

69 Art. 14 of the 2012 Law on Education (op.cit. note 29). 
A common opinion is that many students for whom languages other than Russian are native (in the sense of their belonging to a non-Russian ethnic background) will choose Russian as their native language, as this will prepare them better for the Unified State Exam, the secondary school-leaving examination. The Unified State Exam may only be taken in Russian, ${ }^{70}$ and Russian and mathematics are its two compulsory subjects (thus, the issue of secondary school diplomas and access to higher education depend on satisfactory results in these two disciplines). ${ }^{71}$ Another trend is the further strengthening of the role of the Russian language. As the state language, Russian was (even before the amendments) required to be studied in every school; its position has now been strengthened by prescribing that it could also be taught during native language classes. That is, for children who have not chosen any other language, Russian lessons will be doubled in volume (being simultaneously the 'state language' and 'native language').

It is doubtful that the purpose of these changes was to support the Russian language per se: according to the 2010 Census, Russian was the language spoken by $137,494,893$ out of $138,312,535$ persons who took part in the census; ${ }^{72}$ rather, it seems more likely that the real aim was to prevent the compulsory

70 "Na 90\% nashli obshchij yazyk": Gosduma prishla k «formule Babicha» - obyazatel'no, no po vyboru" [We have found the $90 \%$ of common language: State Duma reached the "Babich formula' - compulsory, but voluntarily] BusinessOnline (6 June 2018), available at https://mariuver.com/2018/o6/o6/zakonpr-pererab/.

71 The "unified state examination" (Edinyi Gosudarstvennyi Ekzamen -EGE), the final secondary school examination, to be taken entirely in Russian, was introduced in all regions of Russia by Decree of the Ministry of Education and Science "On the Approval of Regulations on the Methods and Procedures for the State (Final) Certification of Students Having Completed the Main General Education Programs of Full Secondary Education", 28 November 2008, No 362. Previously students from Tatar-medium schools had had the option to take the examination in the language of instruction. The ACFC has stated on this:

$[\ldots]$ the very demanding compulsory curriculum and final examination have largely prompted schools and parents to focus on the main subjects, which in turn diminishes demand for minority language teaching and learning. The Advisory Committee notes that high school graduation or university entry exams provided only in the official language may indeed discourage learning of minority languages at the highest level of proficiency, which can have a negative effect on the acceptance and functionality of these languages in public life. [italics added]

ACFC, op.cit. note 26, para 130. See also ACFC Thematic Commentary No 3, The Language Rights of Persons belonging to National Minorities under the Framework Convention, (May 2012, para 75).

72 All-Russia Population Census 2010. Book 5, "The Language Knowledge of the people of Russian Federation", available at:http://www.gks.ru/free_doc/new_site/perepis201o/croc/ Documents/Vol4/pub-04-05.pdf. 
study of other languages from the "languages of the peoples of Russia" (Russia's regional or minority languages). At the same time, the compulsory study of two foreign languages was not questioned by law-makers: as per the FSES, two foreign languages are included in the mandatory part of the curriculum in addition to Russian and one's 'native language. ${ }^{73}$

Legislators refrained from clarifying whether the choices available to parents and students would include a refusal to study their native languages altogether. If it were possible to opt out, the section of the education program containing obligatory subjects would effectively not be fulfilled. There is no other subject from the obligatory part of the FSES that could be omitted in this way by students. If it were not possible to opt out, a situation would be created where the exercise of a right is transformed into a duty. At the same time, it may not be possible to fulfill the requirements associated with this duty if they are beyond the "the limits of opportunities provided by the education system". This results in a contradiction which has not been resolved either by the legislators or by the courts.

After adoption of the law, the All-Tatar Public Center tried to hold a rally on this issue, but the authorities in Kazan, the capital of Tatarstan, refused to authorize it. ${ }^{74}$ This indicates that, at the regional level, the authorities have sought to comply with the federal center's decision-making, perhaps expecting financial compensation that would mitigate the impact of new linguistic policies. Moreover, so far the new provisions have not been the subject of litigation; yet this might change, as legislators, in adopting new norms, did not take into account some of the principles of judicial practice on languages in education, outlined below.

\section{2} Jurisprudence

Judicial practice evidences that tensions relating to the intersection between linguistic and education rights long predate the Yoshkar-Ola speech. While different positions on the compulsory teaching of regional languages have been taken by the various courts - the Russian Constitutional Court, the Russian

73 For students or their parents there is no right to freely choose to study a certain foreign language (only those foreign languages that are already established in school curricula).

"Tatarskim aktivistam ne razreshili kritiku zakona o rodnyh yazykah - sud podderzhal zapret mitinga" [Tatar Activists were not permitted to critique the law on native languages - court upheld the ban on the rally] Kommersant (30 July 2018), available at: https://www.kommersant.ru/doc/3701082. 
Supreme Court and some of the republics' Supreme Courts - jurisprudence has shaped around a general movement towards a reduction of regional autonomy and increased centralization.

Three main sets of principles emerge from the jurisprudence. The first relates to the right to free choice of language of education, to be balanced against possible obligations imposed on individuals at the regional level (through republican legislation). The second is the balance between federal and republican legislation and competences, themselves linked to the third set of principles: these relate to notions of unity (of the state) and equality (of citizens).

The main judgments relating to the compulsory study of state languages of the republics are described in the table below. The first judgment dates back to 2001, and judicial disputes both preceded and followed the introduction of FSES in 2007. The table below highlights those cases in which compulsory study of the languages of the republics was considered in line with federal legislation.

TABLE of Cases

\begin{tabular}{lll}
\hline Republic & Court & Disputed provision Decision \\
\hline${\text { Altai, } 2001^{\mathrm{a}}}$ & $\begin{array}{l}\text { Russian Supreme } \\
\text { Court (RSC) }\end{array}$ & $\begin{array}{l}\text { Compulsory study of Provisions } \\
\text { republic's language declared invalid } \\
\text { for students of Altai } \\
\text { nationality }\end{array}$
\end{tabular}

Tatarstan, 2004 ${ }^{\mathrm{b}}$ Russian Constitu- Compulsory study Provisions in line tional Court (RCC) of Tatar; Russian with federal and Tatar are legislation studied "in equal measure"

Adygea, 2006 ${ }^{\mathrm{c}} \quad$ Supreme Court of Compulsory study of Provisions the Republic of Adyge language for declared invalid Adygea students of Adige ethnic background

\begin{tabular}{lll}
$\begin{array}{l}\text { Karachay RSC } \\
\text { Cherkessia, 2009 }^{\mathrm{d}}\end{array}$ & $\begin{array}{l}\text { State languages } \\
\text { compulsory for } \\
\text { native speakers }\end{array}$ & $\begin{array}{l}\text { Provisions in line } \\
\text { with federal } \\
\text { legislation }\end{array}$ \\
\hline
\end{tabular}

a Russian Supreme Court, Judgment of 1 September 2001, N 52-Go1-7.

b Constitutional Court of the Russian Federation, Judgment of 16 November 2004, No 16-P.

c Supreme Court of the Republic of Adygea, Judgment of 19 December 2006, No 3-32/2006. 


\begin{tabular}{|c|c|c|c|}
\hline Republic & Court & Disputed provision & Decision \\
\hline Chuvashia, $2011^{\mathrm{e}}$ & RCC & $\begin{array}{l}\text { Compulsory study of } \\
\text { the Chuvash } \\
\text { language for all }\end{array}$ & $\begin{array}{l}\text { Provisions in line } \\
\text { with federal } \\
\text { legislation }\end{array}$ \\
\hline Komi, $2011^{\mathrm{f}}$ & $\begin{array}{l}\text { Constitutional } \\
\text { Court of the } \\
\text { Republic of Komi }\end{array}$ & $\begin{array}{l}\text { Compulsory study of } \\
\text { Komi for all }\end{array}$ & $\begin{array}{l}\text { Provisions in line } \\
\text { with federal } \\
\text { legislation }\end{array}$ \\
\hline$T u v a, 2012^{g}$ & RSC & $\begin{array}{l}\text { Equal functioning of } \\
\text { Tuvan and Russian; } \\
\text { compulsory study of } \\
\text { the two languages } \\
\text { from the level of } \\
\text { pre-school } \\
\text { education }\end{array}$ & $\begin{array}{l}\text { Provisions } \\
\text { declared invalid }\end{array}$ \\
\hline Sakha, $2015^{\mathrm{h}}$ & RSC & $\begin{array}{l}\text { Compulsory study of } \\
\text { Sakha for all }\end{array}$ & $\begin{array}{l}\text { Provisions } \\
\text { declared invalid }\end{array}$ \\
\hline
\end{tabular}

d Russian Supreme Court, Judgment of 15 April 2009, N 30-ГО9-3.

e Russian Constitutional Court, Judgment of 27 January 2011, No 88-O-O.

f Constitutional Court of the Republic of Komi, Judgment of 1 September 2011.

g Russian Supreme Court, Judgment of 18 April 2012, No 92-APG12-4.

h Supreme Court of the Republic of Sakha (Yakutia), Judgment of 29 May 2015.

SOURCE: OWN RESEARCH [FROM ACCESS TO COMMERCIAL DATABASES]

\subsection{Overview ofJudgments}

While taking into account all the cases listed in the table, we focus on two main judgments: on Tatarstan and Sakha. The first of these is a landmark case, in which judicial practice supported the republic's right to introduce the compulsory study of its official language: the judgment of the Russian Constitutional Court (RCC) of 16 November 2004 (hereinafter the Tatarstan case). The RCC's ruling referred to a complaint brought by a resident of Tatarstan, who disputed a set of language provisions in the republic's legislation, including the constitutionality of the compulsory study of Tatar and Russian "in equal measure" in the republic's schools. The RCc held that issues of linguistic policy cannot be managed exclusively by the subjects of the Federation; nevertheless, the RCC took into account the legal significance of the recognition of Tatar as the "state language of the republic" and its function in the public sphere, buttressed by constitutional guarantees. The RCc concluded that, in order for Tatar to be used in the republic's administration, the republic may legally require compulsory 
study of that language within its schools. Consequently, Tatarstan's legislation was found not to violate the Russian Constitution or the right to choose the language of instruction. The RCC's decision became a precedent that was cited in rulings from Chuvashia, Komi and Karachay Cherkessia. ${ }^{75}$

The second judgment on which we focus (and the most recent on the issue under consideration) was delivered by the Russian Supreme Court (RSC) in relation to the Republic of Sakha/Yakutia, and the compulsory study of the Sakha language (also known as Yakut), considered in 2015 (the Sakha case). ${ }^{76}$ The RSC referred to an infringement of the right to choose the language of instruction, and to the fact that the content of education cannot be regulated at the level of the subject, but has to reflect FSES requirements.

The first observation that can be drawn from the cases included in the table is that they reveal disagreements between state actors. For example, in Adygea, while the republic's Ministry of Education and Ministry of Justice took the position that the compulsory study of Adyge violated federal legislation, the republic's president and parliament ${ }^{77}$ disagreed. In the cases examined here, provisions on the compulsory study of regional languages were challenged by republics' residents or prosecutors (or deputy prosecutors), while the legislatures sought to defend their right to adopt and apply such provisions. Noteworthy is also the fact that some of the same principles were upheld in different cases, yet with courts reaching different conclusions. For example, in the cases of Altai, Adygea and Sakha, the courts referred to the principle that nobody can impose limits or privileges concerning the use of a particular language; the same principle was recalled with reference to Karachay Cherkessia: in the first set of cases, provisions for the compulsory study of languages were declared invalid, while in Karachay Cherkessia they were held to be compatible with federal legislation.

Diverging opinions on the delimitation of the republics' powers - and their balance against federal competences - at least partially derive from a lack of legal clarity. Indeed, while Article 14(3) of the Law on Education stipulates that the study of state languages of a republic may be introduced on its territory, the same law does not specify whether this should be a compulsory subject. The republics, in their own legislation on the use of languages in education, in most cases reproduce the same (unclear) principles. The resulting legal uncertainty has led to the courts being called upon to shed light on these issues.

75 These cases are outlined in this section. See also the Table of Cases.

76 Russian Supreme Court, Judgment of 23 September 2015, No 74-APG15-20.

77 The State Council of the Republic of Adygea ('Khase'). 
The matter of free choice of language of instruction has been raised in repeated instances. In Altai and Adygea, the courts reasoned that the disputed provisions obstructed free choice of language of communication, education, and artistic expression. In Adygea, the Republic of Adygea's Supreme Court spelled out that "nobody may oblige a person to learn a language against their will"78 - thereby anticipating the position taken by the Prosecutor General's Office in 2017..$^{79}$ The RCC took a different position in Tatarstan (and later Chuvashia), which was replicated by the Constitutional Court of the Republic of Komi. In the latter cases, the courts held that republican provisions on the study of their official languages in the republics' schools did not violate the constitutional right to freely choose the language of education, provided that the study of these languages took place in accordance with federal legislation and standards. Yet, as noted, frequent disagreements have related to striking a balance between federal and regional competences.

\subsection{Balancing Federal and Regional Competences}

All judgments - including those supporting the right of a republic to declare the study of its language(s) compulsory - referred to the notion that education has to be provided in full compliance with federal standards. The courts have held that the federal authorities were responsible for regulating teaching of Russian as the state language of the Federation, alongside teaching of official and other languages in the republics; in turn, republics' laws could not interfere with the compulsory study of Russian on the basis of federal standards, or restrict the rights of physical or legal persons in the education sphere set by federal law. ${ }^{80}$

\subsubsection{Devolution of Competences}

From this common starting point, in some cases federal competences were treated as delimiting (and superseding) the republics' ability to legally require compulsory study of their state languages; in others, these competences were judged compatible with forms of autonomy in the regions. In Tatarstan, the RCC, on the one hand, stressed the authority of the federal center in devising linguistic policies, including those affecting the state languages of the republics; on the other, compulsory study of regional languages in the republics' schools was held, in principle, not to contradict federal legislation. ${ }^{81}$

78 Adding "with the exception of cases foreseen by the legislation of the Russian Federation".

79 See above ("1.3 The Language Dispute").

8o See Tatarstan, Karachay Cherkessia, Sakha.

81 See also Chuvashia. 
Significantly, in Karachay Cherkessia (2009), the RSC stated that, while FSES fall within the competence of federal executive bodies, this "does not imply the revocation of the powers of a subject of the Russian Federation to create the necessary organizational, financial and other guarantees to meet educational needs and requests of citizens in the study of the state languages of the republic". This principle, the RSC held, arose from the (later repealed) 1992 Federal Law "On Education",82 according to which the study of the state languages of Russia's republics was regulated by the legislation of the republics themselves ${ }^{83}$ (this provision was excluded from subsequent legislation).

When the compulsory study of regional languages was found to be in line with federal legislation, the courts referred to the functionality of the language, and Russia's history of multilingualism. In Tatarstan, the obligation to study Tatar was linked, inter alia, to enabling use of the language in regional administration. These principles were reiterated by the RCC in 2011, in Chuvashia. On this occasion, the RCC restated the same position with reference to the language debate in Tatarstan, and reconfirmed that the compulsory study of Tatar created the conditions for exchanges with state organs in that language. Similarly, in Komi, the Republic's Constitutional Court held that, in order to ensure preservation and development of the titular language and its use in all spheres of official and interethnic relations, the republic had the right to mandate the study of Komi as part of general education programs. The Court stated that:

The right to receive basic general education in the mother tongue and the language of national education [...] pursues the constitutionally significant goals of preserving and developing the languages of the peoples of the Russian Federation and meets the demand in the area of education content, in terms of promoting cooperation and mutual understanding between people and peoples regardless of their national or ethnic origin. [italics added]

Two years earlier, in Karachay Cherkessia the Rsc had also noted that the disputed norms - stating that the republic's state languages are to be taught as compulsory subjects in Russian-language schools ${ }^{84}$ - was addressed "not to

82 Law of 10 September 1992, No 3266-1. The law was repealed and replaced in 2012.

83 Art. 6(6) of the 1992 Law. The RSC further referred to Art. 29(1) of the 1992 Law, which stated that the subjects had the authority to develop and implement regional programs on education, "taking into account national and regional socio-economic, environmental, cultural, demographic and other features".

84 For persons who are "speakers of the language". Art. 7(6) of the Law of the Republic of Karachay Cherkessia “On Education”, 6 January 1998, No 376-XXI. 
citizens [...] but to educational institutions". Thus, the provisions should not be treated as an imposition on citizens, but as crystallizing the responsibilities of schools to provide the relevant language courses. The RSC explained:

[I]t is clear that [the provision] has a positive objective. In essence, it sets forth measures for the performance of educational institutions, not with the aim of creating obstacles in the study of state languages, but with the aim of excluding possible unjustified denials by educational institutions to citizens to study their chosen state language of the republic; and, therefore, it guarantees access to the study of state languages of the subject of the Russian Federation [...] [at various levels of education]; this is in line with the requirements of federal legislation regulating the principles of language policy, including those disputed [...] in the present case.

This last citation reveals recognition of the importance of positive action in creating the conditions to sustain multilingualism in the education system, and enabling its functionality. ${ }^{85}$ Yet the law that contained the disputed provision was repealed and replaced by another in November $2009,{ }^{86}$ just a few months after the Karachay Cherkessia judgment (April 2009).

\subsubsection{Prevalence of Federal Competences}

A different approach was taken by the RSC in Tuva (2012) and Sakha (2015). ${ }^{87}$ In Tuva, the Rsc reversed a judgment of the Supreme Court of the Republic of Tuva (SCRT), on the possible incompatibility with federal law of provisions contained in Tuvan legislation on the study of the Tuvan and Russian languages starting with preschool institutions. ${ }^{88}$ The SCRT rejected the case of incompatibility, pointing to distinct competences for republican and federal authorities. The RSC disagreed, ${ }^{89}$ stating that, contrary to the SCRT's interpretation, federal legislation ${ }^{90}$ stipulates that the requirements for the study of languages

85 The Rsc added:

The right of citizens of the Russian Federation to receive education in their native language is ensured by the creation of the necessary number of relevant educational institutions, classes, groups, as well as the creation of conditions for their functioning.

86 Law of the RKC of 2 November 2009, No 50-RZ.

87 See also Adygea and Altai.

88 Together with the study of national customs and ethics. Art. 7(2)(3) of the Law of the Republic of Tuva "On the Languages in the Republic of Tuva", 31 December 2003, No 462 BX-1.

89 The appeal was brought to the Rsc by the parliament of the Republic of Tuva.

9o The court referred to Arts. 6, 7, 9, 10, 12, 13, 29 of the 1992 Federal Law "On Education" (later replaced by the 2012 Law "On Education in the Russian Federation" - op.cit. note 29), and 
are to be set at federal level. Preschool education, around which the case centered, was held to be among the programs of general education regulated at federal level, through establishment of mandatory federal regulations for implementation of education programs. The disputed norm in Tuvan legislation was declared invalid from the time the judgment entered into force. ${ }^{91}$

In Sakha the RSC reiterated the principle that the content of education cannot be regulated at the level of the subject, but has to reflect the FSEs's requirements, and that the subjects' legislation may not limit the rights and guarantees laid down by federal law. The RSC did acknowledge that the competences of the Federation's subjects "include the development and implementation of regional programs for the development of education, taking into account regional socio-economic, ecological, demographic, ethno-cultural and other features of the subjects". ${ }^{92}$ Yet, as noted, the "national-regional component" was removed from the legislation and FSES in $2007,{ }^{93}$ resulting in a greater role for individual schools (in compliance with federal standards) but a reduced one for republics. ${ }^{94}$ Thus, in Sakha the RSc held that "neither the Federal Law 'On Education in the Russian Federation' nor [the FSEs] provide the subjects of the Russian Federation with the authority to establish requirements for the content of education programs." Instead, "this authority can be exercised in ways provided for by the Federal Law 'On Education in the Russian Federation', that is, by participating in the expert assessment of samples of basic general education programs, of textbooks, etc." 95 This approach differs substantially from that which the RSC had taken in 2009 in Karachay Cherkessia, outlined above, which had supported a devolution of powers.

Sakha further refers to the fact that "policy and legal regulation of relations in the sphere of education are based on the principle of unity of the education space on the territory of the Russian Federation". ${ }^{96}$ The concept of "unity of the education space" had been recalled in previous judgments, such as Tatarstan,

Arts. 9 and 10 of the 1991 Federal Law "On the Languages of the Peoples of the Russian Federation" (op.cit. note 34).

91 Art. 7(2)(3) was removed with Law of the Republic of Tuva "On the Amendment of the Law of the Republic of Tuva on Languages in the Republic of Tuva", 9 July 2012, No 1470 BX-I, after the provision was declared invalid.

92 The RSC cited Art. 8 of the 2012 Law on Education (op.cit. note 29).

93 See section on "Languages in the Education System: Law and Practice".

94 See also the RSC cases from 2009, 2011 and 2015, on Karachay Cherkessia, Tuva and Sakha respectively.

95 The Sakha judgment reiterated that: "education in the state language of the Russian Federation is guaranteed, as well as the choice of the language of instruction within the limits of the opportunities provided by the education system".

96 The Rsc cited Arts. 4, 12 and 14 of the 2012 Law on Education (op.cit. note 29). 
and has been a feature of Russian legislation. ${ }^{97}$ In Sakha, however, a stronger emphasis is placed on unity, with the RSC pointing to the Republic of Sakha's "violation of the principle of unity of the federal cultural and educational process", and republican authorities also having "illegally restricted the use of the state language of the Russian Federation". ${ }^{98}$ The RSC referred to principles arising from, inter alia, a Decree of the Ministry of Education and Science on FSES ${ }^{99}$ stating that the FSES "are aimed, in particular, at ensuring the unity of the education space of the Russian Federation; preservation and development of cultural diversity and linguistic heritage of the multinational people of the Russian Federation [...]" (Point 4). ${ }^{100}$ This type of statement reflects a tension between "unity of the education space" and (cultural and linguistic) diversity in Russia as a multi-ethnic federation. The judgment, supporting the view that Sakha had exceeded its legal powers, implies that this tension is to be resolved through centralized regulation. Finally, we should note that in no case did the courts consider whether the FSES requirements themselves may violate the right of a republic to establish their own state language(s), enshrined in the Constitution, taken in conjunction with the right to require their study, included in the Law on Education.

The RCC has not been called upon to decide in cases relating to the constitutionality of the compulsory study of regional languages in a republic since 2011. It remains an open question whether, like the Rsc, it would reverse its earlier position and embrace greater centralization, to reflect developments at the federal level. Nevertheless, the overall trajectory of jurisprudence, together with the effects of the language dispute following the Yoshkar-Ola speech, point to the balance increasingly tipping towards federal regulation of the use of languages in the education system. These developments are accompanied by movements supporting the primacy of the Russian language, consolidating the view of Russian as (as Putin put it in Yoshkar-Ola) "the natural spiritual framework of our multinational country".

\footnotetext{
97 E.g., see Arts. 3(1)(4) and 11(1) of the Law on Education (op.cit. note 29).

98 This view had already been presented in the judgment by the Sakha Supreme Court.

99 Decree "On Approval of Federal State Educational Standards of Basic General Education", 17 December 2010, No 1897, available at http://base.garant.ru/55170507/.

100 The RSC also cited Art. 3(1)(4) of the Law on Education (op.cit. note 29) as "one of the basic principles of state policy in the field of education". It states:

1. State policy and the legal regulation of relations in the sphere of education is based on the following principles:

[...]

4) unity of educational space in the territory of the Russia Federation.
} 


\subsection{Equality and Equal Opportunities}

In some cases the requirement to study particular languages (or through the medium of those languages) was considered from the point of view of equality - by the applicants or by the courts, or both. In Adygea (2006), the argument presented by the applicant (the republic's deputy prosecutor) was that, on the one hand, citizens of the Russian Federation have a constitutionallyentrenched right to receive basic education in their native language, and the legislature of the Republic of Adygea had acted within its rights by including the study of the Adige language as part of its program of general education. On the other hand, the applicant submitted that the introduction of Adige as a school subject for Adige students "cannot be categorical, as it leads to violation of the principles, guaranteed by the Russian Constitution, of equality of human and civil rights and freedoms, and citizens' exercise of equal duties throughout its territory, including in relation to realization of the right to education and language rights and freedoms." [italics added]. ${ }^{101}$ This view was shared by the Supreme Court of the Republic of Adygea, which held that the disputed provision was indeed in violation of federal law due to its "categorical character". Compulsory study of regional languages has also been interpreted as a source of discrimination when confined to individuals with the relevant ethnic background (as has been the case in some republics, including Adygea). ${ }^{102}$

In Tatarstan, the applicant similarly argued that republican provisions prescribing intensive study of Tatar reduced students' opportunity to "deepen the study of other subjects of the curriculum, and also of optional disciplines"; as a consequence, "those who reside in the Republic of Tatarstan therefore are in an unequal position in realization of the right to education compared to those living in other subjects of the Russian Federation, which violates the guarantees of this right [of equality] under the Constitution" [italics added]. ${ }^{103}$ The RCC, in

101 The applicant referred to Arts 9(1) and (2) of the Law "On the Languages of the Peoples of the Russian Federation" (op.cit. note 34), relating to the right of free choice of language of education.

102 E.g., in Altai, the obligation to study the Altai language was considered to infringe the rights of citizens on the grounds of social, racial, national, linguistic or religious origins in light of the fact that it applied specifically to residents of Altai ethnic background.

103 Similarly, in the Karachay Cherkessia case, the applicant argued that the requirement to study the state languages of the Republic in question violated the equality of rights and freedoms of citizens residing therein. The Supreme Court of the Republic agreed with this interpretation, although the case was later overturned by the RSC. 
its ruling, stated that intensive study of Tatar ${ }^{104}$ per se could not be regarded as an obstacle to equality: Russian (as the country's state language) and Tatar (as the state language of the republic) performed different functions, and Tatarstan had acted within its rights in introducing a legal requirement that the Tatar and Russian languages be studied "in equal measure" in the republic's schools $^{105}$ (granted that this occurred within an overarching federal education framework, as noted above). Equality was still brought into the judgment: it was reasoned by the RCC that, "unlike the Russian language, the Tatar language is not a state language of the territories of other subjects of the Russian Federation." Discrepancies in requirements on the study of Russian at the level of the republics could lead to potential "negative consequences in relation to the continuity of learning in a single federal educational environment". This was linked by the RCC to violations of the principle of equality in the realization of the right to education, as well as freedom of movement and choice of place of residence. The teaching of Tatar could not challenge the status of Russian as the only state language of the Federation, and could not be "to the detriment of the federal component of the basic federal curriculum [...] or be an obstacle to realization of the right of students to deepen their learning of other subjects of the curriculum, including Russian [...]." Hence, it was envisaged that all students would be taught according to the same educational standards with regard to the main subjects of the curriculum (including Russian). Meanwhile, the judgment added a form of protection for students with limited knowledge of Tatar, by stating that they should experience no obstacles in their final examination, award of a diploma, or in their access to higher education. ${ }^{106}$

In another case considered by the RSC, ${ }^{107}$ the study of Russian (along with the obligation to take the final secondary school examination in Russian only) was connected to pre-empting violations of the principle of equality, and to equal opportunities in accessing higher education and professional life. Following the same reasoning, the Russian authorities motivated a refusal to

104 "In equal measure" with Russian, Art. 8 of Constitution of Tatarstan, and Article 9(2) of the Law "On the State Languages of the Republic of Tatarstan and Other Languages in the Republic of Tatarstan", 8 July 1992, No 56o-XII.

105 A person residing in Tatarstan had argued that the provision in Tatarstan's legislation violated the right to equality, as persons from Tatarstan were in an "unequal" position compared to persons in other subjects: the obligation to learn Tatar detracted from the hours that could be devoted to other school subjects.

106 On these principles, see also the Komi and Chuvashia cases.

107 RSC, Appeals Chamber, Judgment of 2 July 2009, No KASo9-295. 
allow pre-school education in the Republic of Karelia to take place exclusively in the Karelian language by stating that the nurseries in question created a "closed language environment within the frames of pre-school institutions": 108 "[i]n [the] multinational environment of Russia this would significantly reduce their socialization opportunities and, accordingly, would entail [a] violation of the principle of equal opportunities of education, further employment etc. [...]" [italics added]. ${ }^{109}$ Finally, elements of the principle of equality can be found in the Yoshkar-Ola speech, where Putin stated that every Russian citizen must speak Russian, referring to standardized efforts to teach Russian in schools in line with the FSES.

This approach to equality reflects a perspective of formal equality, in the sense that all persons are treated in the same manner. It differs from substantive equality in the sense of special measures to create equal opportunities even in the presence of cultural and linguistic diversity. ${ }^{110}$ For example, the latter approach is evidenced in the Framework Convention for the Protection of National Minorities (FCNM): while stressing the importance of national minorities' societal integration, the treaty also refers to measures for the promotion of "full and effective equality between persons belonging to a national minority and those belonging to the majority" [italics added]. ${ }^{111}$ Substantive equality is reflected in the concept of "group-differentiated rights", 12 by which special support is provided to particular communities, with the objective of creating the conditions for advancing equality, in substance, rather than an 'equality' based on 'sameness'.

108 In a report to the Council of Europe's Advisory Committee on the Framework Convention for the Protection of National Minorities. (Third) Report submitted by the Russian Federation, 9 April 2010, ACFC/SR/III(2010)005, 102.

109 Ibid.

110 See also Federica Prina, "Linguistic Rights in a Former Empire: Minority Languages and the Russian Higher Courts", 10 European Yearbook of Minority Issues (2011), 61-89.

111 Art. 4(2), FCNM, ratified by Russia in 1998. Similar provisions are included in Art1(4) of the 1966 UN International Convention on the Elimination of All Forms of Racial Discrimination (ICERD), ratified by Russia in 1969, which refer to "special measures taken for the sole purpose of securing adequate advancement of certain racial or ethnic groups or individuals requiring such protection as may be necessary in order to ensure such groups or individuals equal enjoyment or exercise of human rights and fundamental freedoms [...]" [italics added].

112 Will Kymlicka, Multicultural Odysseys: Navigating the New International Politics of Diversity (Oup, Oxford, 2007); Will Kymlicka, Multicultural Citizenship: A Liberal Theory of Minority Rights (Clarendon Press, Oxford, 1995). 
Putin's Yoshkar-Ola speech and the prosecutorial inspections that followed can be located within the broader dynamics of centralization of the education sphere and promotion of unity through uniformity. This article has focused on the advancement of linguistic uniformity, through policies that construct the Russian language as a unifying factor, or "the natural spiritual framework of our multinational country", as stated by Putin in the Yoshkar-Ola speech. The reduction of the scope of the republics' rights to promote their official languages, along with tendencies towards the standardization of language policies in schools (presented as 'equality'), suggest that assimilatory tendencies hide behind discourses on national unity. While not new, these dynamics seem to have gained momentum since Putin's speech, while recent legal changes have been made in disregard of principles arising from past judicial practice.

In the balancing between federal and republican competences (and between centralization and devolution), the former have gained greater prominence. The effects have been an increased emphasis on Russian and the marginalization of regional languages, along with the shrinking of the regions' autonomy in the education and linguistic spheres. Moreover, the republics' participation in devising curricula and textbooks is confined to recommendations, which is not guaranteed to impact upon decision-making at the federal level. These practices escalate the application of uniform education and linguistic policies across the Federation.

While the jurisprudence on republican languages in the education system is relatively small, their incidence reveals center-periphery disputes, which have been, inter alia, considered by the Russian higher courts. Public debates and protests have also unfolded within the republics themselves, with private citizens also participating in these actions, including taking cases to court. Meanwhile, the jurisprudence has reflected a general shift towards centralization of the education sphere, with a new emphasis on 'unity', particularly through the 2015 Sakha judgment. ${ }^{113}$ Significantly, no courts have raised the question as to whether the FSES requirements themselves may violate the right of a republic to establish its own state language(s) (enshrined in the Constitution) taken in conjunction with the right to require their study (included in the Law on Education). Cautionary language has repeatedly been employed

113 As noted, the Sakha judgment refers to "unity of the federal cultural and educational process". 
in judgments, for example by stressing that teaching of a republic's language(s) must occur "not to the detriment of the study of Russian". The arguments made by the applicants in these cases seem to expose a preoccupation that the teaching of regional languages may erode the knowledge of Russian, and its primacy as the country's state language. Some judgments have resulted in provisions on the compulsory study of republican languages being declared invalid. ${ }^{114}$

The actions of the Prosecutor General's Office have similarly followed prevailing tendencies towards centralization of the education space. The position of the Prosecutor General's Office - crystallized following Putin's speech - is that, despite the fact that republican languages may be used in administrative bodies, their study may not be mandatory in schools, unlike for other subjects in the curriculum, such as Russian itself. Restrictions on the use of regional languages in the education system began prior to the prosecutorial inspections; at the same time, the inspections have displayed (what seem to be) punitive attitudes, and fueled tensions already present in the regions. And, following the inspections, some republics have amended their legislation, to exclude or dilute the obligation to study titular languages in the republics' schools.

While federal legislation in principle allows the republics to make the study of regional languages compulsory, this practice is effectively prevented by bylaws (FSES) and new amendments to the Law on Education. Uniform requirements on the content of education in practice obstruct the right of the Federation's subjects to realize their internal language policies. The reasons for this obstruction remain unknown; however, if we consider the length and the public character of the dispute, the incidence of protests in the regions, as well as the existence of legal means which could resolve the impasse (which have, however, been neglected), one may speculate that such reasons are primarily political. Rights are recognized and provided for in the law and judicial practice but subsequently eroded. Despite state narratives of Russia's linguistic diversity, assimilation in practice tends to advance, jeopardizing the future of the country's multilingualism.

114 Altai, Adygea, Tuva, Sakha. 